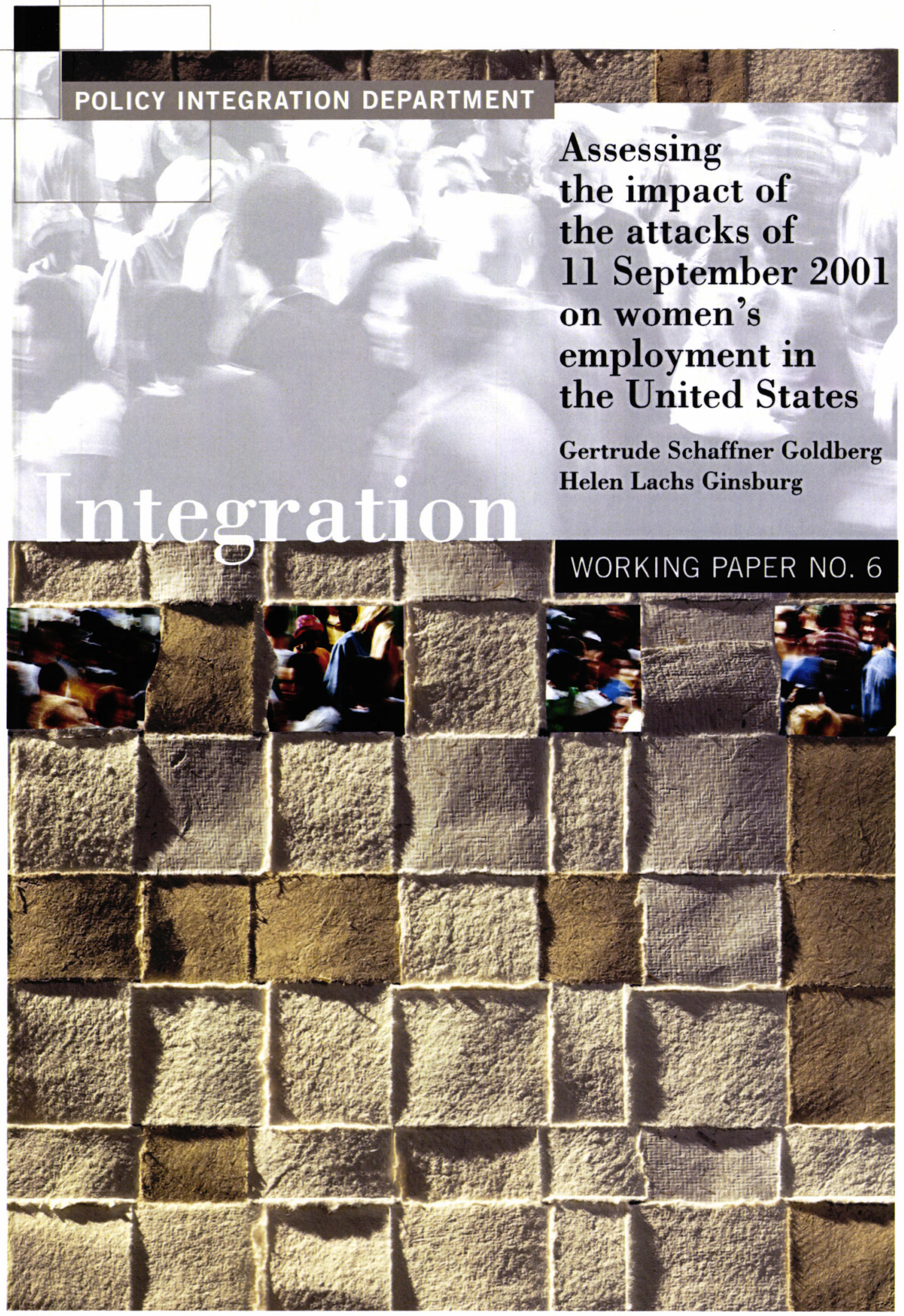





\section{Assessing the impact of the attacks of 11 September 2001 on women's employment in the United States}

Working Paper No. 6

\section{Gertrude Schaffner Goldberg and Helen Lachs Ginsburg}

\section{Policy Integration Department International Labour Office \\ Geneva}

October 2003 


\section{Copyright $\mathbb{C}$ International Labour Organization 2003}

Publications of the International Labour Office enjoy copyright under Protocol 2 of the Universal Copyright Convention. Nevertheless, short excerpts from them may be reproduced without authorization, on condition that the source is indicated. For rights of reproduction or translation, application should be made to the ILO Publications Bureau (Rights and Permissions), International Labour Office, CH-1211 Geneva 22, Switzerland. The International Labour Office welcomes such applications.

Libraries, institutions and other users registered in the United Kingdom with the Copyright Licensing Agency, 90 Tottenham Court Road, London W1T 4LP [Fax: (+44) (0)20 7631 5500; email: cla@)cla.co.uk], in the United States with the Copyright Clearance Center, 222 Rosewood Drive, Danvers, MA 01923 [Fax: (+1) (978) 750 4470; email: info@copyright.com] or in other countries with associated Reproduction Rights Organizations, may make photocopies in accordance with the licences issued to them for this purpose.

ISBN 92-2-113484-9

The designations employed in ILO publications, which are in conformity with United Nations practice, and the presentation of material therein do not imply the expression of any opinion whatsoever on the part of the International Labour Office concerning the legal status of any country, area or territory or of its authorities, or concerning the delimitation of its frontiers.

The responsibility for opinions expressed in signed articles, studies and other contributions rests solely with their authors, and publication does not constitute an endorsement by the International Labour Office of the opinions expressed in them.

Reference to names of firms and commercial products and processes does not imply their endorsement by the International Labour Office, and any failure to mention a particular firm, commercial product or process is not a sign of disapproval.

ILO publications can be obtained through major booksellers or ILO local offices in many countries, or direct from ILO Publications, International Labour Office, CH-1211 Geneva 22, Switzerland. Catalogues or lists of new publications are available free of charge from the above address. 


\section{Assessing the impact of the attacks of 11 September 2001 on women's employment in the United States}

\section{Contents}

Preface

1. 11 September, recession and the economic context ....................... 1

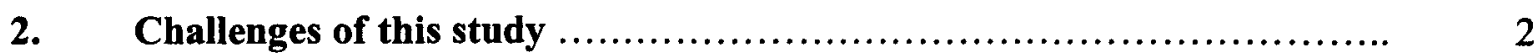

3. The Economic boom, income distribution, and wages.................. 3

4. Prior estimates of effects of the events of 11 September.................. 4

5. Employment before and after 11 September: Our analysis .............. 5

5.1 Special note on the airline industry and women workers.............. 11

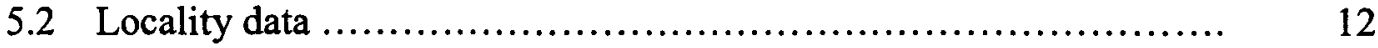

a) New York City .......................................... 12

b) The other ground zero .................................... 15

c) Away from "ground zeroes" ............................... 15

6. Unemployment benefits ......................................... 17

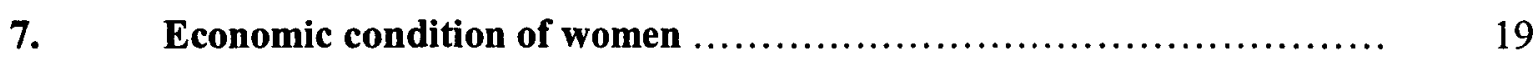

8. Conclusions......................................................... 20

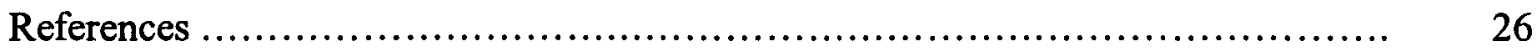





\section{Preface}

The current working paper traces its origins to a discussion in the $\amalg O$ Governing Body Committee on Employment and Social Policy. At its March 2002 session, the Committee examined a document entitled "Policy responses to the employment and social consequences of the events of 11 September 2001" (GB.283/ESP/2). Since that time a wider range of consequences of $9 / 11$ has become apparent, but the immediate question then, beyond the death and destruction caused by the attack itself, was the impact on economic growth and employment. Among the issues examined, one was whether the employment impact was greater on women than on men. In order to explore this question further, the Office commissioned the working paper which follows, which examines specifically the impact in the United States.

Professor Gertrude Schaffner Goldberg of Adelphi University and Professor Emerita Helen Lachs Ginsburg of Brooklyn College took up the challenging task of rapidly examining the available data and information. The major difficulty they encountered was separating out the impact of 11 September from general economic trends, which were mixed at the time they completed the study (July 2002).

While pointing out the shortcomings in the statistics at hand, the authors conclude that the evidence does not indicate that women were disproportionately affected overall. The proportion of women affected by redundancy in the economy as a whole (both announced and actual layoffs) was comparable to their share of all workers. A more detailed assessment of the situation in New York was also unable to confirm a differential effect on women, although it was found that the impact was greater among low income workers.

However, a differential impact on women was found in sectors which were most directly affected by the events of 11 September - air transport and the travel industry generally, retail trade, hotels and manufacturing - where women's employment fell by proportionally more than men's.

The working paper recalls that women's wages are on average some 25 per cent lower than men's, that 60 per cent of low wage workers are women, and that women are less likely to be eligible for unemployment and welfare benefits than men. So those women who were affected may well have had less of a safety net to protect them. The authors thus recommend reform of the unemployment insurance and welfare systems.

The interviews conducted by the authors reveal interesting observations from a variety of sources. In general, the trade unions received good marks for lobbying efforts that benefited both union and non-union workers who were thrown out of jobs. It is also observed that government response to the situation was greater than in an ordinary recession.

Looking to the future, the authors also point to issues that might benefit from further research, such as a comparison of a "hands off" approach by some states affected by postSeptember 11 unemployment in the tourist industry and that of Hawaii, which mitigated the negative employment effects by direct job creation and government bonds for construction. 
In the spirit of all working papers, this one is intended to stimulate debate. Around the globe, we live in a post-11 September world, with fresh challenges calling for solid research and creative responses.

The views expressed are those of the author.

30 October 2003

Gerry B. Rodgers

Policy Integration Department 


\section{Assessing the impact of the attacks of 11 September 2001 on women's employment in the United States}

\section{11 September, recession, and the economic context}

The terrorist attacks of 11 September 2001 on the World Trade Center and the Pentagon directly resulted in a loss of nearly 3,000 lives and significant economic disruption. Did these assaults on human life and property in the United States impact the employment of women more than the employment of men? This was the key question posed in this study, undertaken in the first half of 2002.

How large an economic and employment impact in the United States could be expected from the events of 11 September 2001? In an economy of over ten trillion dollars and a labour force numbering 142 million people-four-fifths the size of the European Union, how likely is it that such a vast economy would be measurably shaken by an attack on three buildings, however large and symbolically significant? A mid-range estimate of the value of the World Trade Center, the destruction at the Pentagon and the associated physical capital would be $\$ 50$ billion, 1/600th of the United States capital stock (Neely, 2002).

The effects of the attacks on all workers in the United States are not easy to determine, let alone the effects on women's employment. One reason is that the United States economy had already begun to slide. At the time that they occurred, the attacks were expected to compound the economic recession. Yet, responses of government, voluntary organizations, and the general public to this unprecedented attack on American soil may have restrained a recession, one that was milder than some previous downturns and that by July 2002 was seen as officially ended (Pastor \& Zabin, 2002). Economist Gregory DeFreitas believes that the principal reason gross domestic product rose since September 2001 is "the sharp increase in government activity since then". Thanks to huge jumps in military and domestic security operations, airline subsidies, higher unemployment and health care benefits, federal spending rose 13 percent from October 2001 to February 2002, double the usual increase. The Federal Reserve's deep interest rate cuts also stimulated car sales and home buying (DeFreitas, 2002, 3; see also Madrick, 2002; Leonhardt, 2002; Zaccone, 2002). Operating in the opposite direction are other, subsequent phenomena, such as the revelation of corruption and even collapse of once solid and respected corporate giants. These too could be factored into this nearly insoluble equation. 


\section{Challenges of this study}

In addition to the near intractable difficulty of disentangling the economic impact of 11 September from the general economic downturn, there are other problems in studying its effects. At least three definitional issues are discernible: the time frame, geographic area, and industries.

To begin with, there is the question of what time period should be considered. As Gordon Pavy, a researcher for the American Federation of Labour-Congress of Industrial Organizations (AFL-CIO), who tracked announced layoffs following the attacks reported to us, the further one gets from 11 September, the more difficult it is to attribute these job losses to the attacks (interview with Gordon Pavy, 27 June, 2002).

The immediate or short-term impact is not necessarily the same as the intermediate or long-term impact. For example, the gender composition of workers laid off immediately after the terrorist attack may differ as the economic fallout spreads more diffusely to other industries. Further, in the long nun the industrial composition of the labour force might change due to economic factors related to the attacks. For example, if more people continue to drive or take trains rather than fly to vacation or business destinations, the industrial and gender composition of the labour force could change. Similarly, if political priorities change in response to the attacks, that, too, has gender implications. If these events provide a rationale for a long-term expansion of the military budget-and the social budget remains the same or contracts - the effect of such policies would be to shift more resources to men's employment.

A second definitional issue is the geographic area that is being considered. As noted, in a nation the size of the United States, even the displacement of many workers may be washed away in national figures. Also, the employment impact varies from one location to another. Some areas, such as those in or near the immediate vicinity of the World Trade Center in New York, were heavily impacted and, to a lesser extent, the Washington, DC metropolitan area, where a major airport was closed for more than a month. Some air hubs or areas highly dependent on tourism, for example, Florida or Las Vegas, Nevada, were also affected while some parts of the United States appear to have been virtually unaffected. Further, even in impacted areas, the industry mix and consequent effects vary.

A third issue, one that is closely related to time frame and geographical definitions, is that of the particular industries affected by the attacks. Some industries, such as airlines and hotels, were immediately impacted. Others, such as retail trade and some types of manufacturing, followed suit. On the other hand, some industries, such as detective and armored car services, greatly increased hiring in response to the attacks (Langdon, McMenamim, \& Krolik, 2002). Another factor that complicates this analysis is that some of the affected industries, like the airlines, were already having difficulties before the recession or the 11 September attacks (Armshaw, 2001). In any case, the impact on women will vary depending on the gender profile of the industries that are affected positively or negatively by the attacks. 


\section{The economic boom, income distribution and wages}

The events of 11 September and the recession followed an unprecedented economic boom but one that nonetheless left many people behind. The second half of the 1990s were years of increasing economic inequality in the United States. In 2000, income inequality of United States households was the highest (according to the gini coefficient) since the Census Bureau began keeping such records in 1967, and the share of aggregate income received by the highest one-fifth of households was almost 14 times that of the lowest fifth. The top 20 percent of households earned only slightly less than the other 80 percent (49.6 percent compared to 51.4 percent) (United States Bureau of the Census, 2001, table A-2).

Wages rose during the boom but, in 1999, real average weekly earnings were 11 percent below their 1973 level (Mishel, Bernstein, \& Schmitt, 1999, table 3.3). The minimum wage rose from its nadir in the preceding decade but was nowhere near an anti-poverty wage. In 2000 , a minimum-wage worker employed full-time, year-round earned only 80 percent of the poverty level for a three-person family $(\$ 13,470)$. Here, too, the decline in economic prospects for low-wage workers is apparent. In 1968, the minimum-wage worker could expect 128 percent of the poverty level for full-time, year-round work. Women constitute the majority of minimum-wage workers.

Official unemployment was at a 30 -year low in 1999, but there were nearly six million persons who were officially unemployed, over three million who were involuntary part-time workers, and an estimated 16.7 million workers earning less than the paltry poverty level for a family of four (Ginsburg, 2000, using data of the United States Bureau of Labour Statistics and the United States Bureau of the Census). At the same time that labour market and income inequality rose, the social sector that might have mitigated these conditions began to be cut back. Demographic factors, such as an increase in single-parent households and an aging population, called for a growth in social programs, but they instead shrank (Goldberg, 2002).

\section{Prior estimates of effects of the events of 11 September}

Announced layoffs. Several estimates of the employment impact of the events of 11 September on women were available to us. Gordon Pavy, a researcher for the (AFL-CIO) tracked layoffs related to the attacks that were announced in the press in the six weeks following the attacks--from 12 September, 2001 through 24 October, 2001 (Pavy, 2002). Of the total of 639,000 workers, Pavy estimated that 45 percent would be women, less than the proportion of women in payroll employment. Two-thirds of the estimated total worked in only three sectors. The largest number of persons projected to be laid off were in manufacturing (25.2 percent), followed by hospitality, tourism, and entertainment (21.3 percent), with transportation ( 20.3 percent) a close third. Two-thirds of the women were also in the same three sectors, but the hospitality, tourism, and entertainment industry was tops for women (30.7 per cent), followed by manufacturing (23.1 percent) and transportation (12.9 percent). 
Announced layoff data, however, are problematic. We do not know if the layoffs actually took place or even if they will take place. If the latter, they may occur over several years, and some may be accomplished by attrition. Further, announced layoffs only capture the intent of firms large enough to be reported in the press, thus excluding layoffs made by small firms as well as small layoffs of large firms. These estimates also exclude the selfemployed.

Government data on extended mass layoffs. The United States Department of Labour, Bureau of Labour Statistics (BLS) regularly and carefully collects data on actual extended mass layoffs of 50 or more persons by an establishment at a single physical location and lasting for more than 30 days. Data are from each state's unemployment insurance database and subsequent employer interviews. After the terrorist attacks the BLS developed a method of identifying layoffs of workers "directly" (in the immediate area of the World Trade Center in New York City) attributable to the attacks, or "indirectly" attributable to the attacks, for example, airlines and hotels and motels (United States Department of Labour, Bureau of Labour Statistics, 2002b; 2002d).

The impact of the 11 September attacks was swift. Data covering the period through 30 March 2002 show that 68 percent of the worker separations occurred in the month immediately following the attacks, and 87 percent had occurred by 17 November, 2001 . Although 33 states reported mass layoffs related to the 11 September events, slightly over half ( 53 percent) of the separations took place in just five states: California, Illinois, Nevada, New York and Texas. California is the most populous state and is an important destination, especially for foreign tourists. New York was the main site of physical destruction. Nevada, the center of gambling in the United States, is highly dependent on tourism and Illinois and Texas are important airline hubs.

As of 30 March, 2002, 122,777 persons affected by these mass layoffs had initiated a request for unemployment insurance, nearly half ( 49 percent) of them women. Close to nine out of ten ( 86.5 percent) of initial claimants had been employed in only three broadlydefined industries: just over one-third had worked in accommodation and food service industries (mostly in hotels), the same proportion as in transportation and warehousing (mostly in air transportation); and nearly one in five was employed in manufacturing. For both men and women the same three industry groups dominated, accounting for about the same proportion of claimants. However, a higher proportion of women than men was employed in the accommodation and food service sector and the transportation and warehousing sector, and a considerable proportion was in manufacturing.

While useful, extended mass layoff data cannot give a complete picture of the impact of the 11 September attacks. Among the unemployed persons not counted include those working for establishments that laid off fewer than 50 people; those whose layoffs lasted less than 31 days; persons ineligible for unemployment benefits (disproportionately women and lower-wage workers) or who are eligible but do not apply for benefits; and the selfemployed. 
New York City estimate. Another estimate, but one that has no gender breakdown, was done by economist James Parrott of the Fiscal Policy Institute (2002) who studied the employment impact of 11 September on New York City. Parrott estimated a World-Trade Center-related job loss in New York City during the fourth quarter of 2001 of about 73,900 , with most of the loss displacing low-wage workers in the restaurant, retail, wholesale and hotel industries. It should be noted that some of these jobs were not lost to the national economy but rather relocated outside New York City.

Clearly, estimating job losses attributable to 11 September, whether or not gender is considered, is imprecise at best.

\section{Employment before and after 11 September: Our analysis}

The Bureau of Labour Statistics collects non-farm payroll employment data on specific industries and locations, both of which would be expected to yield answers to the questions raised in this paper (United States Department of Labour, Bureau of Labour Statistics, 2002e). The industry figures for the nation, but not the localities, are available for women. We analyzed the national data on employment for all employees and for selected industries thought to be seriously affected by the terrorist attacks. Study of localities that were severely impacted might well have provided some answers to our questions, but we were quite hampered by the absence of gender breakdowns in these data. Nor did we encounter any studies, national or local, that looked systematically at the impact of the 11 September events on women's employment or economic condition. In discussing localities, we will summarize pertinent parts of reports by state, local, and nongovernmental bodies as well as our interviews with representatives of business, labour, and others from various parts of the country.

What the industrial data show. In this analysis we examined data for all employment in the economy; for manufacturing which was thought to be showing signs of recession before 11 September; and for those industries thought to be affected most by the attacks: air transportation, transportation services, retail trade, hotels and other lodging places, and eating and drinking establishments. Within two of these industries are sub-categories considered especially vulnerable: travel agencies (classified as transportation services) and scheduled air travel (in the transportation by category).

Table 1 below gives the number of employees in industries of particular relevance to this study and the proportion of women in them in 2001. Women were almost 49 percent of employed workers. Although they were less than a third of the workers in manufacturing, the number of women in manufacturing is nonetheless larger than in any of the affected industries except retail trade. 
Table 1: All employees and percent women employees in selected, non-farm industries 2001

\begin{tabular}{l|c|c}
\hline & Number (000) & $\begin{array}{c}\text { Percent Women } \\
\text { Women }\end{array}$ \\
\hline All industries & $131^{\prime} 922.0$ & 48.7 \\
Manufacturing & $17^{\prime} 695.0$ & 31.4 \\
Transportation by air & 1266.00 & 38.3 \\
$\quad$ Air transport, Schedule & 581.2 & 44.5 \\
Transport Services & 462.8 & 57.2 \\
Travel Agencies & 160.5 & 78.3 \\
Retail Trade & $23^{\prime} 522.00$ & 52.5 \\
Eating and drinking places & 8256.9 & 55.1 \\
Hotels and motels, other lodging & $1 ' 870.00$ & 56.3 \\
\hline
\end{tabular}

Source: United States Department of Labor, Bureau of Labor Statistics, unpublished payroll data, July 2002

We have observed employment trends for the total economy and for selected industries for three time periods: Time 1. from March 2001 to September 2001 (pre 11 September); Time 2. from September 2001 to December 2001 (immediate post 11 September); and Time 3. from September 2001 to March 2002 (intermediate post 11 September). Because seasonally adjusted figures are not available by gender, we have compared changes in employment in the year of the attacks and the first three months of the following year (Year of the Attacks), with comparable intervals in 2000 and the first three months of 2001 (Previous Year). Table 2 presents changes in employment for the three time periods for the Year of the Attacks for all workers and for women workers. Table 3 presents data for the three time intervals in the Previous Year. Table 4 compares the changes in total employment and women's employment in the Previous Year and the Year of the Attacks. Although figures for men are not given, they are readily grasped from data on all employees and women employees. 

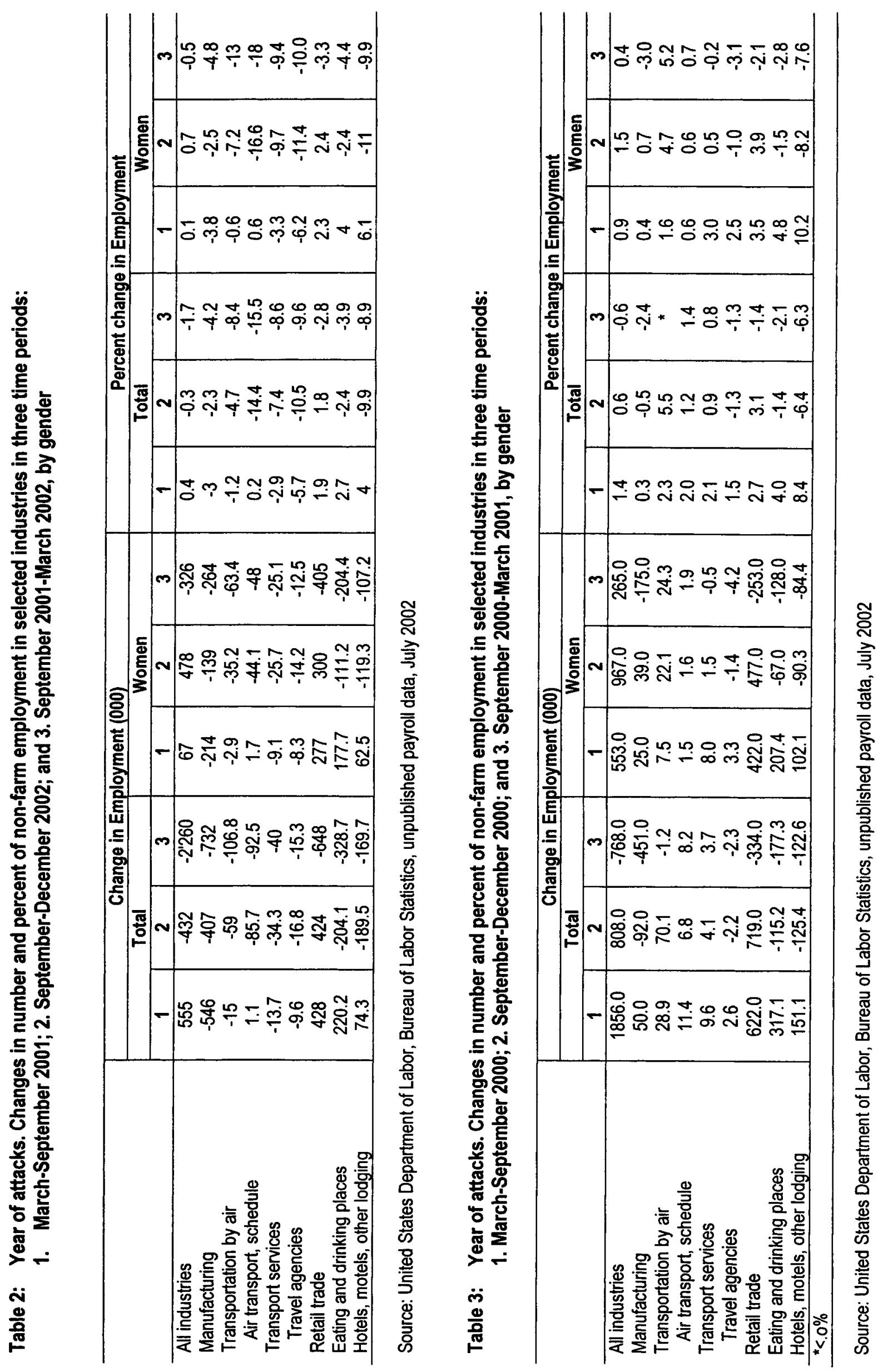


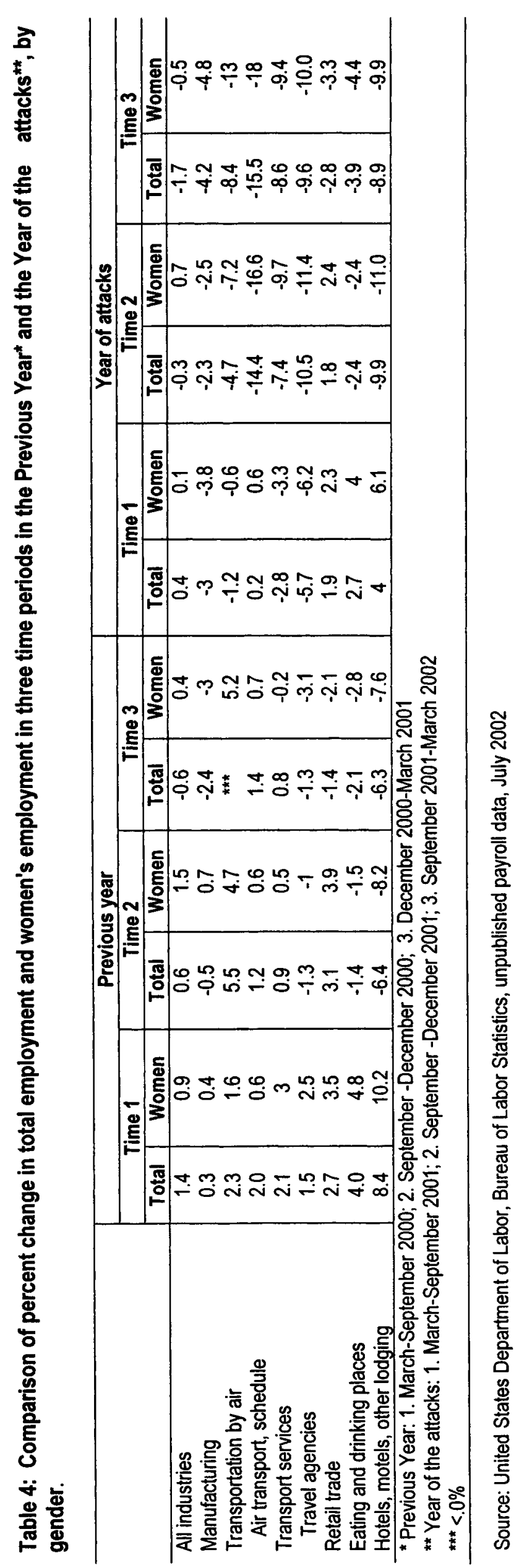


The picture for employees in all industries is different from that of the affected industries. The National Bureau of Economic Research, which traditionally pronounces the beginning and end of recessions, later deemed the recession to have begun in March 2001. Yet, the six months in 2001 prior to the attacks saw a gain of over half a million jobs, an increase of .4 percent (Table 4). This gain, however, was considerably less than the 1.4 percent gain in the comparable six months in 2000 . Growth had clearly slowed. Women's employment rose .1 percent, compared to .9 percent the previous year. Women also lagged behind men the previous year, but the gains for both were larger in 2000 .

In the first three months after 11 September, there was a loss of 432,000 jobs or .3 percent, but nonetheless, an increase in women's employment of .7 percent (Table 2). In the previous year (Table 3 ), total employment grew by .6 percent and women's by more than double (1.5 percent) the 2001 rate. In the intermediate term (Time 2), however, the economy lost over 2.2 million jobs or 1.7 percent of payroll. In this intermediate period women lost ground but less than men (.5 percent vs. 1.7 percent). In the previous year, overall losses were much smaller (.6 percent), and women actually gained (.4 percent). Clearly, total payroll fell after the attacks, but in the immediate aftermath women's employment did not. Women did slip in the intermediate term but not as much as men.

A press release from the Institute on Women's Policy Research reported that the unemployment rate for men in November 2001 was 6.0 percent, compared to 5.5 percent for women. The rate was especially high for women who maintain families ( 8.3 percent) and adult black women ( 8.7 percent). Adult black men fared even worse ( 8.8 percent), and the rate for all blacks, including youth, was higher than that (10.1 percent) (Institute for Women's Policy Research, 2001, using data from United States Bureau of Labour Statistics and United States Department of Labour, Current Population Survey).

Signs of recession were apparent in manufacturing in the pre 11 September (Time 1) interval in 2001, when payroll declined by over half a million jobs or 3 percent. Women, who are less than a third of the employees in manufacturing, lost disproportionately to their numbers, accounting for nearly two-fifths of the total job loss in that industry. In the preceding year, manufacturing had grown .3 percent, and women had fared slightly better. In the three months after 11 September (Time 2) manufacturing lost ground at a faster rate than in the preceding six, with women's losses being slightly disproportionate to their numbers. In the same interval in the previous year, there was a total loss of jobs in manufacturing ( 5 percent), but women actually gained somewhat $(.7$ percent). Whereas women in manufacturing did better than men in the September to December period in 2000, they did a little worse than men in the comparable three months immediately following the attacks, when both lost ground. In the six months following the attacks (Time 3), total job loss numbered 732,000 . Women's losses continued to be proportionately greater than men's.

In reports based on its payroll data, the Bureau of Labour Statistics concluded that, "It is not possible to separate overall job losses for October 2001 and subsequent months into the effects from the 11 September events and the effects from a generally weakening employment trend that had been evident for several months prior" (United States Department of Labour, Bureau of Labour Statistics, 2002a). The Bureau, however, went on to state "that several industries with substantial employment declines in October and some subsequent months ... have undoubtedly been affected by the aftermath of the terrorist 
attacks and the widespread decline in travel following September 11" (ibid.). It is to these industries that we turn, both to analyze the effects of 11 September and the impact on women workers.

In transportation by air, both total and women's employment fell in the six months prior to 11 September, but women's fell less than men. By contrast, in the previous year, both gained, but women less than men. This industry had begun to slide before the events of 11 September (see below). Immediately after that, total employment fell by 4.7 percent, but women's dropped even more sharply, by 7.2 percent. In the longer term (Time 3 ), the fall was even greater for the industry, with women's proportionate losses continuing to be much greater than men's. Revealing the effect of 11 September is the fact that total employment in air transportation gained substantially in the September to December interval the previous year. In the September to March period (Time 1) of the year before the attacks, women continued to gain substantially, but men suffered a very slight loss (less than 1 percent). Clearly, women had substantially greater losses in the 11 September aftermath.

In scheduled air travel, a sub-category of transportation by air in which women are a larger proportion than in the industry as a whole, there were gains for men in the Previous Year, but less for women. Scheduled air travel as a whole did considerably less well in the six months preceding 11 September than in the comparable period in the preceding year, but women did better than men and gained about the same as in 2000. After 11 September, erosion was very heavy, with women's relative losses considerably more than men's. In fact, the women's 18 percent decline in the intermediate aftermath (Time 3) was the highest in any of the time intervals that we considered. With the exception of the months immediately preceding 11 September women had gained much less than men, and after the crisis, they lost disproportionately.

Transportation services, because they include all forms of transportation, did less poorly in the post 11 September scenario than transportation by air, but the industry nonetheless suffered substantial losses. Women lost in the 10 percent range in both the immediate and intermediate aftermath. The industry picture was clearly different from the previous year in which small gains were registered, except for women in the third (September to March) interval. Already, in the pre 11 September period, the industry had lost ground. Women who, in the comparable period the previous year made gains exceeding those of men, slipped more than their male counterparts in the months preceding the attacks. The industry losses in transportation services began before 11 September, but the aftermath saw a dramatic change and relatively greater losses for women.

Travel agencies, a sub-category of transportation services in which women hold nearly four-fifths of the positions, suffered a reverse of fortune in the year preceding 11 September. Whereas there had been a small gain in the March to September period (Time 1) in 2000, with women faring better than men, the industry lost ground in the next three intervals preceding 11 September. In the interval (Time 1) immediately preceding 11 September, the industry lost 5.7 percent of payroll employment, with women's losses being greater than men's. Nonetheless, the aftermath of 11 September witnessed a dramatic change: job losses in the 10 percent range. Women's relative losses in both post 11 September intervals were even greater than men's.

Retail trade, a large industry in which women are the majority, gained less in the March to September (Time 1) interval of the attack year than in the comparable period in the preceding year. Women were gaining more than men in three of the four periods prior to 11 September, but in the September 2000 to March 2001 interval (Time 3), they both lost, women somewhat more than men (.7 of a percentage point). Immediately after 11 September 
women gained ( 2.4 percent), but less than in the same months a year earlier ( 3.9 percent). In the intermediate aftermath (Time 3), however, they lost more ground than in the previous year and had relatively greater losses than men.

Eating and drinking establishments registered larger gains for women in the March to September interval (Time 1) in both the Previous Year and the Year of the Attacks. Gains for the total industry were lower in the six months prior to 11 September than in the comparable interval in the previous year, but women's gains were higher than men's both years. There were little or no gender differences in the job losses in the last quarter (Time 2) of both the Previous Year and the Year of the Attacks, but the losses for both were greater in the 11 September year. Losses continued for the rest of the post-11 September period. They were greater for the six-months after 11 September and larger than in the previous year. In the intermediate period (Time 3), women's losses were relatively greater than men's (about 13 percent more).

The hotel industry registered gains in the pre 11 September months but not nearly as great as a year earlier, perhaps an early sign of a downturn. In both years, women fared better than men in the interval that includes the summer vacation months (Time 1). Losses for the industry were substantial in the post-11 September intervals, with women faring worse. The effects of 11 September and the recession are apparent, and women's losses are not only proportionately larger than men's but greater than their losses in the year before 11 September.

Our conclusion from these employment data is that in the post 11 September scenario women suffered disproportionately in all the affected industries that we examined but not in the economy as a whole where their job losses were proportionately less than those of men. These employment figures, of course, do not tell us anything about reduced work time, pay cuts due to reduced hours or compensation per hour, and access to unemployment insurance or other benefits. There were, indeed, economic reasons for both sexes to be concerned. A survey of 1,000 women in November 2001 found that in the wake of the terrorist attacks and biochemical threats (anthrax), women were more concerned about a sagging economy and their economic vulnerability than about personal safety (Richards, 2002).

\subsection{Special note on the airline industry and women workers}

Of all of the industries impacted by the events of 11 September, none has been more dramatically affected than the airline industry. Flight attendants, the occupation emblematic of women in the airline industry, were among the workers most severely dislocated by the attacks. According to a researcher for the Association of Flight Attendants (AFA), the AFA, with a membership of about 50,000, represents about half of U.S. flight attendants; 85 percent of AFA members are women. (Some other unions represent flight attendants, and some are nonunion.) In mid-July 2002, ten months after the attacks, some 16,000 flight attendants were still furloughed, including 6,400 AFA members (Interview with Theresa McGlauflin, July 15, 2002).

While the airline industry, as already noted, had begun to slide in the period prior to 11 September, its problems go back further to the onset of deregulation policies in the late 1970s that ushered in a period of competitive pressures resulting in losses, mergers, and bankruptcies. For workers this meant job losses and more pressures (Ward, 2002). Speaking at the January 2001 meeting of the Industrial Relations Research Association (IRRA), AFA President Patricia Friend cited a factor in the labour relations climate at the time: from 1995 through 2000 , profits of the top five airlines totaled more than $\$ 17.6$ billion. Friend stated 
that if the average flight attendant's starting pay of $\$ 12,253$ had grown at the same rate as CEO salaries during those years, their starting pay in 2001 would be $\$ 80,367$, instead of $\$ 14,824$ (Armshaw, 2001).

The $\$ 15$ billion loan and grant package for the industry, enacted by Congress after 11 September, neglected workers. Moreover, regulations of the Office of Management and Budget (a unit of the Executive Branch of the national government) state that airlines getting these loans and grants should "provide a demonstration of concessions by the air carrier's security holders, other creditors or employees" (cited in Ward, 2002). Recently, United Airlines, which would like a $\$ 1.8$ billion loan guarantee, called for $\$ 950$ billion in concessions from labour over three years (Wong , 2002c). The Airline Pilots Association approved the package, which appears to be less unfavorable to this male-dominated union; the AFA did not. Federal officials have said that they will give backing to the bailout money "only if airlines are able to come up with a stringent business plan which would include proof that they can cut labour costs" (Wong, 2002a, C3). In mid-July, a US Airways loan guarantee for $\$ 900$ million was approved if several conditions are met. One of them is to "obtain greater concessions from its unions" (Wong, 2000b, C1).

Before 11 September, Thomas Kochan, professor of management at the Massachusetts Institute of Technology, observed that "airlines are very important to the economy, and for those in labour relations because of the industry's high visibility and high level of unionization" (Armshaw, 2001). Unions are an important means by which women workers, in particular, reduce their disadvantaged status. Encouraging airlines to wring concessions from unions could harm labour generally and set back attempts to organize more women and low-wage workers. This approach to labour relations, given a boost by the 11 September events, could be one of the most profound, long-run, negative consequences of the terrorist attacks.

\subsection{Locality Data}

Research reports, newspaper articles, and extensive telephone interviews yielded considerable information about the impact of 11 September on areas that were either the actual sites of the attacks or thought to have been especially vulnerable to their impact. However, these sources provided only a limited amount of data on women's employment.

\section{a) New York City}

Naturally, New York City, the site of extensive loss of lives and property on 11 September, has been the subject of most study. Our principal sources of locality data are reports by the following organizations: the Fiscal Policy Institute (FPI), a nonprofit research and education organization focusing on New York tax, budget and economic issues (FPI, 2001a; 2001b; 2002); the Center for the Study of Labour and Democracy at Hofstra University in Long Island, New York (DeFreitas, March 2002); the United Way of New York City, the organization that solicits funds from individuals and businesses throughout the city and allots them among voluntary social agencies (March 2002); and the Asian American Federation of New York, a not-for-profit organization providing public policy and community service leadership to identify and meet the critical needs of Asian Americans in the New York metropolitan area (April 2002).

In an article entitled "Recession and Rebuilding in New York City," Gregory DeFreitas, Director of the Center for the Study of Labour and Democracy, wrote that the events that displaced over 100,000 workers, obliterated at least 15 million square feet of prime office 
space (equivalent to 15 Empire State Buildings), and destroyed or forced to relocate hundreds of businesses, transformed the city's economic future for at least the next few years. In the last quarter of 2001 , the city's economy shrank by 4.4 percent at the same time that the overall United States economy expanded 1.7 percent (DeFreitas, 2002, 3).

The reports emphasized the economic toll on lower-wage workers or immigrants. The title of the November report of the Fiscal Policy Institute is "World Trade Center Job Impacts Take a Heavy Toll on Low-Wage Workers" (2001b). All five of the occupational categories incurring the greatest number of layoffs related to the 11 September attacks were lower-wage: waiters and waitresses, janitors and cleaners, retail salespersons, food preparation workers, and cashiers. Median wages in these five occupations ranged from $\$ 7.08$ an hour to $\$ 14.18$ (FPI, November 2000 , table 3). Restaurants and retailing, it should be noted, have been important sources of job opportunities for the large number of persons, principally women, who have left the welfare rolls in recent years (United Way, 2002, 26).

Estimating layoffs at 79,680 (a figure subsequently reduced to 73,900), the FPI reported that the average wage of 60 percent of the laid off workers was $\$ 11.00$ an hour, an annual salary of $\$ 22,880$ (FPI, 2001b, table 2; FPI, 2002 for revised estimate). This is above the low poverty line for a family of three but below the Economic Policy Institute's $\$ 14$ an hour $(\$ 29,120$ annual) "basic needs" budget for a one-parent, two-child family. It is less than half the $\$ 45,852$ "self-sufficiency" annual budget for the New York City borough of Brooklyn (Bernstein, 2000). ${ }^{1}$ In three occupations alone, garment workers, taxi, livery and black car workers, and graphic designers, the Fiscal Policy Institute estimated that 76,000 workers were working reduced hours (FPI, 2001b, table 2). Calling attention to the thousands of New Yorkers who suffered a reduction in earnings as a result of having their work hours cut back, the United Way observed that "many families of low-wage workers who had just been getting by have consequently fallen back into the ranks of the working poor" (UW, 2002, 3).

New York's Chinatown in lower Manhattan, close to but not immediately adjacent to the World Trade Center, was not physically damaged, but streets were blocked, disrupting commerce and tourism. Consequently, it suffered "an unprecedented level of unemployment and underemployment" (AAFNY, 2002, 3) ${ }^{2}$ An estimated 24,500 of the 33,658 workers in Chinatown were temporarily dislocated in the two weeks following 11 September, and 23 percent of the working population $(7,685$ people) were laid off in the first three months after the attacks. Workers, who were largely blue-collar and service employees earning low wages to begin with, lost pay as a result of dislocation, temporary or extended lay-offs, and reduced working hours. Five months after 11 September over 70 percent of garment workers and 35 percent of restaurant workers - the two largest categories of affected workers, were still

1 The self-sufficiency standards are based on actual costs of basic goods and services in specific areas. Whereas the federal poverty line for a family with one parent, one preschooler, and one school-age child was $\$ 14,150$ in 2000 , the self-sufficiency standard put the amount at $\$ 46,836$ in the New York City Borough of Queens (Bernstein, 2000).

2 This report was prepared with the assistance of the Federal Reserve Bank of New York, the Fiscal Policy Institute, and the Ralph and Goldy Lewis Center for Regional Policy Studies at the University of Califomia, Los Angeles, an Academic Advisory Committee of six respected researchers, and a Community Advisory Committee of 16 community leaders. 
working reduced hours (AAFNY, 2002, 26-33). The severe losses in Chinatown are one reason, but by no means the only one, that Mark Levitan, senior policy analyst at the Community Service Society of New York, considers the employment impact in New York "an immigrant story" (Interview with Mark Levitan, July 2, 2002). ${ }^{3}$ The immigrant story, however, is part of the larger story of the disproportionate impact on low-wage and workingpoor people.

To what extent is the New York experience a "woman's story?" According to DeFreitas' calculations from the Current Population Survey of the Bureau of Labour Statistics, the unemployment rate for women was 7.7 percent, compared to 7.3 percent for men in the last quarter of 2001, whereas the rate in other big cities was the same for both sexes as well as lower (7.2 percent) than in the heavily damaged New York City (DeFreitas, 2002 , table 2). However, a higher rate of unemployment for women than for men in New York City is not an 11 September phenomenon. The unemployment rate for all foreign-born persons was somewhat lower, 7.1, but the highest rates were for teens, 16-19 (22.2 percent), blacks (10.5 percent), and persons of Spanish origin (9.9 percent).

The underemployment rate, which includes official unemployment, plus involuntary unemployment and worker discouragement, was also somewhat higher for women than men in the months following 11 September - 13.1 percent compared to 12.9 percent. This too was different from other big cities (DeFreitas, ibid.). These figures given by DeFreitas are the only systematic ones for gender for New York City.

We discussed the gender breakdown with several trade union officials in the hard-hit Hotel Employees and Restaurant Employees Union (HERE). According to a researcher for Local 100, Food Service Union of HERE, 300 workers out of 6,000 represented by the union were displaced by the events of 11 September, but only 30 were women. (Interview with Amanda Ream, July 15, 2002). Ream said the effects for restaurant workers were reduced schedules, half the hours, or reduced tips. The 11 September attacks, she observed, were "an excuse for getting rid of people they were already having difficulty justifying."

We expected to find greater disadvantage for women in the hotel industry, which is 56 percent female, nationwide. John Turciano, a spokesperson for the Hotel Trades Council of New York, representing 90 percent of the employees in New York City hotels, maintains that lay-offs of 4,800 of their 25,000 workers were roughly split between men and women. Whereas speed-ups for housekeepers, nearly all women, were reported in some other cities (see below), Turciano maintains that in their strong, militant union-hotel workers in New York City are the most highly unionized in the country-this was not the case (Interview with John Turciano, July 25, 2002).

Taking the hard-hit workers in Chinatown, we find that one of the two occupations that suffered most, garment workers, is composed almost exclusively of immigrant women (Wong, 2002). The other, restaurant workers, is predominantly male. According to the Fiscal Policy Institute, the City's 11,000 corporate black car drivers faced reported fare losses of 80 percent.

3 The Community Service Society is one of the oldest and most respected social service agencies in New York City. For many years it has had a distinguished social research unit. 
In short, we simply do not have the data to declare that the effects of the 11 September attacks in New York was a "woman's story." Women's slightly higher unemployment and underemployment rates in the immediate aftermath are not enough to make that judgment, and some other, largely anecdotal evidence, may point toward a roughly equal burden.

\section{b) The other ground zero}

The United States Pentagon, located in the state of Virginia, very close to Washington, D.C. and Ronald Reagan National Airport, was the other "ground zero". In the wake of the attack on the Pentagon, that airport was closed for at least a month, temporarily laying off 10,000 workers. John Foster Dulles International Airport, also in the Washington, D.C. metropolitan area, was closed, too, but not as long. Most of the persons thrown out of work live in the District of Columbia (D.C.) or Virginia.

The Washington Metropolitan Council AFL-CIO Community Service Agency provided emergency help to workers affected by the crisis, only half of whom are unionized. The director of this service, Kathleen McKirchey, estimated a 60-40 breakdown of women and men in the highly affected hospitality industry (Interview with Kathleen McKirchey, July 8, 2002). According to McKirchey, cab drivers at the Reagan airport, mostly male, were greatly affected. Burdens for immigrants, including their greater difficulties in becoming reemployed, were emphasized.

Jorge Rivera, an official of the Local of the Hotel Employees and Restaurant Employees Union (HERE) in Washington, D.C. reported that of the union's 8,000 members, 5,000 were initially without work (Interview July 9, 2002). Fifty percent hotels in Washington, D.C. are unionized. In every hotel, the largest department is housekeeping, which is 99 percent female. The rest of the unionized departments are approximately half male and female. Most of the laid off workers have been called back but not all; some are only working two or three days a week, and 20 percent are working only sporadically. Immigrant burdens are again cited, including the problems of undocumented aliens who do not even try to get unemployment benefits.

In sum, we are unable to get a general picture of the employment effects in the second "ground zero", much less the impact on women. We do know, however, that the almost exclusively female housekeeping departments of hotels were heavily affected.

\section{c) Away from "ground zeroes"}

The title of a Business Week article, "Wichita [Kansas]: Not So Far from Ground Zero" (Berner, October 8, 2001) suggests how far-reaching the shock waves of 11 September were. In Wichita, 81 percent of manufacturing jobs and 21 percent of total employment are tied up with aircraft and aerospace industries. This mid-western city is illustrative of economies that depend on travel, especially by air, or in which large numbers of people are employed in travel-related industries.

The authors of a report on "The Impact of the Economic Downturn on California Labour" argue that "it was the 'dot.com' crash, rather than 11 Sept., that was the triggering factor" (Pastor \& Zabin, June 2002, 3). Nonetheless, this report, prepared by economists at two research centres in the University of California system, called attention to "the profound effects on travel and tourism and the disproportionate effect on unionized jobs due to the high union density in these hard hit labour markets"(ibid.). According to Pastor and Zabin, the context of this recession in California, mild though it may be, is: 1. the inequality in education, unfavorable public policies, weaker union power that has burgeoned in the last 
decade; and 2. "the new economy," that is, reliance on the temporary labour that has become a permanent feature of the state's labour market and that makes for "a flexibility' that whipsaws regional economies and destabilizes workers' lives and communities" (ibid., 20, 21).

In California, the impact of 11 September was concentrated in three sectors: air transportation, amusement, and hotels, which had a net job loss of approximately 27,000 jobs in the last quarter of 2001. Comprising only 4.5 percent of total jobs in California, these sectors were responsible for one-third of the job loss in the last three months of 2001 . The airlines, as already discussed, were suffering from the global economic slump before 11 September. HERE union locals in San Francisco and Los Angeles each report that about one-third of their members lost their jobs. Budgetary problems at the state level have limited government's ability to cope with the increased need for income support and services generated by the combined effects of recession and terrorist attacks.

Goetz Wolff, research director of the Los Angeles County Federation of Labour, prepared a summary of information about unions affected by 11 September (29 October, 2001). Ten union locals were listed. Two HERE locals representing approximately 12,000 hotel, restaurant, and food service workers had heavy losses; over one-fourth were jobless; and reductions in hours affected the majority of members. In a union representing United Airlines flight attendants, 358 of 3,320 members lost jobs to early retirement or lay offs, and all members were affected with reduced hours, changed schedules, and limited overtime. While the flight attendants' union is likely to have been predominantly women, the 400 to 500 members of a Machinists union, including airport mechanics, customer service personnel, cargo service workers, and ramp service personnel, were likely to have been predominantly male. From this summary of information on affected unions in Los Angeles we cannot determine whether women union members were more seriously affected than their male counterparts, and, of course, this information tells us nothing about the circumstances of the large numbers of workers who do not belong to unions. A HERE official who works in Oakland, California, said that there was little 11 September impact on the union's members in that city because it is more of a "drive in" location, that is, hotels and restaurants do not depend on air travel.

We interviewed people in a number of other areas that were either highly dependent on travel or had a heavy volume of air traffic: Las Vegas, (Nevada), Hawaii, Florida, and Chicago. O'Hare Field, one of two airports in Chicago, has one of the highest air traffic levels in the United States. Whereas HERE members were not affected in Oakland, 600 of the HERE members who prepare food for airplanes in Chicago were laid off, 60 percent or more were of whom were women. Employers have been recalling these workers, and most people are back to work. In hotels the union could track 400 people who were laid off, and 1,000 workers were impacted with shorter hours; there were also speed-ups. Room cleaners, almost 100 percent women, were heavily affected (Interview with Jim DuPont, July 1,2002$)^{4}$

$4 \mathrm{Jim}$ DuPont is an official of HERE in both Oakland and Chicago. 
According to Audrey Arnold of the United Labour Agency of Nevada (AFL-CIO Community and Social Services in Las Vegas), the hypothesis addressed in this paper whether women were more seriously affected in the aftermath of 11 September, is "kind of right," but the trickle down, she believes, is not so correct. Hotels were hurt first, and women were laid off. Then all construction stopped, and male constructions workers were hurt. When they were laid off, Arnold told us, they could not get the same help as "direct" impact industry workers, such as hotel employees. As elsewhere, the housekeeping units, largely female, are the largest single work group in Las Vegas hotels. Initially, at least, there were some problems with speed-ups in the housekeeping units (Interview with Audrey Arnold, 5 July, 2002). (Whereas some union officials report speed-ups in housekeeping, one representative of a hotel chain told of another approach to cost cutting, that is, directing housekeepers to perform more limited maintenance for guests who stay multiple nights (Corcoran, 2002).

The research director of the Florida State AFL-CIO gave anecdotal evidence that travel and tourist industries were hard hit in Florida and that women were the larger proportion of the workers affected. Since these industries are the linchpin of Florida's economy, loss of these jobs led to reductions in service, then retail, then manufacturing employment. Workers in Florida are largely non-union, so one should not generalize from union data that are not systematic to begin with (Interview with Rich Templin, 15 July, 2002).

An economist at the Center for Labour Education and Research at the University of Hawaii had forecasted a much larger rise in unemployment in the state than actually occurred. In fact, he describes post 11 September effects as a "blip in unemployment." Yet, a cruise line employing 5,000 workers, the majority women (60 percent) collapsed two weeks after 11 September. Why was unemployment kept down? Some people left the labour force, and there were reduced hours. The unemployment rate in hotels is about 10 percent. State construction bonds of about $\$ 600,000,000$ helped to offset the effects of 11 September, and there was also a public employment program (Interview with Lawrence Boyd, 9 July, 2002).

\section{Unemployment benefits}

Jobless workers, regardless of gender-whether their unemployment is fully, partly, or not at all related to the 11 September attacks-suffer a significant income loss. Unemployment insurance (UI), their main safety net, is a system replete with holes, through which proportionately more women fall. And even when they do not fall through the net, women receive smaller benefits because of their lower earnings base.

UI is a nearly-seven-decades-old, federal-state program. States must meet certain federal standards but set their own rules governing coverage, benefit amounts, and revenues. The result is a patchwork quilt rife with shortcomings and inequities as well as wide state-tostate variations. States typically pay benefits to qualifying unemployed workers for a maximum of 26 weeks. 
Most of the unemployed in the United States do not receive benefits. In 2001, only 43 percent of the nation's jobless received UI benefits. Proportionately fewer unemployed women than men receive them-40 percent compared to 46 percent. These rates vary widely from state to state (Emsellem, Goldberg, McHugh, Primus, Smith \& Wegner, 2002). Women also face greater obstacles in qualifying for UI benefits because they are more likely to be low-wage, part-time or temporary workers, against whom the system works.

Nearly all states require workers to meet an earnings standard to receive UI. Thus lowwage workers have to work more hours to qualify than better-paid ones, and so they have significantly lower UI recipient rates than better-paid workers (Lovell \& Hill, 2001).

UI employer payroll taxes are paid for part-time workers. Even so, in at least 30 states unemployed persons looking for part-time work are ineligible for benefits, including those who meet minimum earnings requirements (EPI, Issue Guide to Unemployment Insurance, $\mathbf{n}$. d.). For a variety of reasons, such as insufficient earnings or hours worked, temporary workers, roughly three out of five of them women (Mishel, Bernstein \& Schmidt, 2001, table $3.15)$ also fare poorly in the UI system. They may also have difficulty proving they did not voluntarily quit. Further, because up to six months of the most recent earnings are not counted toward earnings requirements, workers who have been at their jobs for a short period of time are often ineligible, and this works against women (EPI, Issue Guide to Unemployment Insurance, n.d.).

Benefits for persons who do overcome the eligibility hurdle are low. In 2001, UI benefits replaced less than half of weekly earnings- 46 percent for men and 47 percent for women. Despite this near gender equality in replacement rates, women's checks were smaller than men's because of their lower earnings: an average of $\$ 211$ weekly, compared to $\$ 259$ for men, with wide state-to-state variation. (For men, these ranged from $\$ 173$ in Mississippi to $\$ 371$ in Massachusetts; women's benefits ranged from $\$ 155$ in Mississippi to $\$ 277$ in Rhode Island.) (United States Department of Labour, Employment and Training Administration, 2002). Benefit amounts, especially for low-income workers, are below the poverty level in many states (Wenger, 2001), and in some states, even the maximum UI benefit is below the government's poverty standard for a three-person family (Emsellem et al., 2002). It is reasonable to infer from these UI data that women who lost their jobs as a result of the events of September 11 th and their aftermath were more disadvantaged financially than men.

Despite the dire economic conditions facing both men and women who lost their jobs in the aftermath of 11 September, it was not until March 2002, six months later, that legislation was unacted to provide an additional 13 weeks of federally financed UI benefits was enacted, an action generally taken in past recessions. This extension of UI benefits was part of legislation that provided huge corporate tax breaks, many times the cost of the UI extension (Ward, May/June 2002). (A small, permanent program, on disaster benefits, provided otherwise ineligible workers with UI benefits-but only about 3,300 nationally-received them (Interview with Darryl Bauman, United States Department of Labour, Employment and Training Administration, 25 July, 2002). By contrast, the federal government provided $\$ 15$ billion in direct grants and loan guarantees to the airline industry almost immediatelywith the first $\$ 2.4$ billion installment provided by 4 October (Ward, 2001). Both houses of Congress defeated amendments to that legislation to expand UI benefits (Ward, 2002).

Many of the industries and areas most impacted by 11 September have a higher union density than the nation as a whole. Research suggests that higher unionization rates result in a higher proportion of unemployed workers filing for benefits because unions typically provide important information to workers regarding rights and benefits (Wenger, 2001). This 
is certainly the case is the aftermath of 11 September. Organized labour, often working in concert with other community groups, helped unemployed workers by informing them how to apply for UI, making it easier for them to do so, and in other ways. This was especially important for immigrants and other workers who tend not to be informed of their rights.

The Los Angeles County Federation of Labour, for example, set up workshops to explain to workers how to file for UI benefits and how to provide for housing and utilities. In hard-hit New York, the Employee Clearinghouse Program-spearheaded partly by the New York State AFL-CIO and the New York City Central Labour Council-served as an employment exchange. In the Washington, D.C. area, the Virginia State AFL-CIO persuaded the state to set up a one-stop center at National Airport (located in Virginia). The Virginia State Labour Federation also mobilized members and legislators to pressure the governor to increase the state benefits by $\$ 100$ a week, and the Washington, D.C .Metropolitan AFL-CIO convinced the governing body of the District of Columbia to raise UI benefits. (This was a temporary measure in place for six months.) The District of Columbia Department of Employment set up a one-stop center for displaced workers at the AFL-CIO cafeteria. Similar efforts were made in Las Vegas and Orlando, Florida, both major tourist destinations. (Bimbaum, 2001).

It is reasonable to assume that, due to these efforts, a higher proportion of workers received benefits-and in a few places larger ones-than would otherwise have been the case. However, the economic problems facing women displaced by the events of 11 September are structural, and larger questions persist about the adequacy of the UI system for both men and women workers.

\section{Economic condition of women}

Whether or not women's employment suffered more than men's in the post 11 September scenario, those women who did lose jobs or whose working hours were reduced are more likely to be at a greater disadvantage than men who experience these losses. Women, despite gains in income and greater access to nontraditional jobs, still have lower wages than men. In 2001, their median weekly earnings for full-time work were just over three-fourths those of men (United States Department of Labour, Bureau of Labour Statistics, 2002c). Women make up 60 percent of low-wage workers (Lovell \& Hill, 2001). In 1999, a year of economic boom, one-fourth of all workers, but one-third of women workers, who worked year-round, full-time, earned less than the poverty level for a family of three $(\$ 13,290)$ (Mishel, Bernstein \& Schmitt, 2001).

One-fourth of women workers, compared to less than ten percent of males, work parttime or less than 35 hours a week. Part-time workers earn considerably lower wages than full-time workers, and they are much less likely to have pension or health benefits or to qualify for unemployment insurance (Wenger, 2000).

Whereas unemployed single mothers who either failed to qualify for UI or exhausted their benefits for insurance could once fall back on an entitlement to public assistance, that protection was lost in 1996 with the repeal of the 60-year-old legislation to provide Aid to Families with Dependent Children. In the same year, benefits available to legal immigrants were also restricted. The post 11 September scenario is also a post-welfare "reform" scenario in which a safety net, never secure compared to other wealthy nations, has been impaired even as the nation as a whole grew richer (Goldberg, 2002). 
The combination of sustained low unemployment and more stringent work requirements in social assistance - a principal component of welfare "reform"-reduced the welfare rolls by 2.3 million families and by 6.9 million recipients between August 1996 and September 2001 (available at http://www.acf.dhhs.gov/news/stats/afdc.htm). Overwhelmingly women, the family heads who have left the rolls and become employed are likely to be in low-wage work and to have worked too little to be eligible to collect UI. Recently employed welfare recipients who become unemployed not only face low wage and part-time barriers but also obstacles resulting from their short job tenure. Estimates vary regarding the likelihood of former welfare recipients to qualify for UI if they become unemployed, perhaps because the proportions who qualify differ, depending on whether or not the economy is in recession. (Holzer, 2000, A-46; Wenger, citing Vroman, 1998).

Those women and men still on the welfare rolls-212,581 families in economically damaged New York City-were under pressure to find jobs at the same time that the combination of recession and the 11 September aftermath were reducing employment prospects, particularly for workers with scant skills. In New York City, retailing and restaurants, two of the important job sources for public assistance recipients, have declined as a result of the World Trade Center destruction, and city and state budgetary problems "will inevitably result in job losses in social services-another major employer of former welfare recipients" (United Way, 2002, 26).

\section{Conclusions}

In this paper we set out to examine whether women's employment is likely to have been more affected by the impact of the events of 11 September 2001 and their aftermath than men's employment. This was a difficult assignment, for it was not easy to separate the effects of a recession already underway from the events of 11 September. It would be hard to avoid the post-hoc fallacy, in any case, but in this situation, data for the period following the hypothesized antecedent variable are incomplete, particularly for gender.

We began the assignment disposed to think the hypothesis seemed likely, given the generally weaker labour market condition of women and the gender composition of some of the highly visible affected industries and occupations. We interviewed a number of advocates of the rights of women workers who might also be expected to think women more beleaguered than men: Carol Rosenblatt, Executive Director of the Coalition of Labour Union Women (CLUW) (1 July, 2002); Ellen Bravo, National Co-director of 9 to 5 National Association of WorkingWomen (8 July, 2002); Karen Nussbaum Director of the Working Women's Department of the AFL-CIO and earlier Director of 9 to 5 (26 June, 2002); Cynthia B. Costello, Co-Editor of The American Woman, a publication of the Women's Research and Education Institute (8 July, 2002); Tim Costello of the North American Alliance for Fair Employment, a network of organizations working on behalf of contingent workers (15 July, 2002); Heather Healy, Director of Employee Assistance Program of the Association of Flight Attendants (AFA) (2 July, 2002); and Carol Eickert, analyst dealing with the condition of working women in the Public Policy Department of the AFL-CIO (3 July, 2002). 
Typical of the responses of these advocates for women workers was that of Carol Rosenblatt of CLUW who thought the hypothesis is probably right but did not think any of the data "had been collated." We found that the data for a definitive answer may not even exist. Ellen Bravo of 9 to 5, whose membership is mostly women in traditionally female, low-wage jobs, considers women "harder hit by the spillover" but does not have hard numbers. Bravo fears that increased job churning and inability to find steady work with sufficient hours will have a negative effect on women trying to move off welfare. Nine to 5 does training for corporations interested in instituting family flexibility policies; after 11 September, several corporations decided to put their participation in flex-time "on hold." Also, Bravo thinks that women, fearing recession and job loss, have become more reluctant to ask for flexible hours even if the company allows them to do it.

Heather Healy of the AFA emphasized the increased stress of many flight attendants, the insufficiency of their new security training (with the result that some attendants have been taking karate courses on their own), and changed schedules and assignments that have been particularly hard on working women who have major responsibility for family care. These interesting interviews provided relevant anecdotal data pointing to hardships for women but not an answer to the question.

Were we able to go beyond the existing analyses of mass layoffs and aggregate unemployment statistics, none of which provided a complete picture of layoffs, much less other effects on workers. The closest we came was with the payroll data that were available by gender. While showing somewhat less job loss for women in the entire, very large United States economy, this data did reveal greater job loss for women in manufacturing; in transportation by air and particularly its sub-category, scheduled air travel; in transportation services and its subsidiary, travel agents; in retail trade, in hotels and motels; and in eating and drinking establishments. We again stress the tentative nature of even these findings, given the difficulty of disentangling the effects of cyclical changes, secular changes, especially in manufacturing, and the unprecedented terrorist attacks. Further, the results of our analysis of national payroll data do not tell another part of the toll of the combined effects of recession and the attacks, that is, reduced working hours, pay cuts, or changes in working conditions. We are certain that these were visited on workers but have not provided systematic data regarding extent or gender.

Locality data were either without gender distinctions or incomplete, so that it is hard to generalize about reported hardships for women workers in hard-hit cities, metropolitan areas, or states. What we do know is that lower-wage workers, including immigrants, tended to be hurt more in the post 11 September scenario and that women nationally are over-represented among lower-wage workers and the working poor.

Part of the post 11 September scenario is compensation for job losses in the aftermath of the attacks. The unemployed and underemployed fell into a safety net, never very supportive, that had been tattered-if not battered-in the preceding decades. Lower-wage workers and women, particularly, are poorly compensated, if at all, under the Unemployment Insurance system. The 1996 repeal of entitlement to public assistance for single mothers and the strict working requirements and lifetime limits of the new law came at time of receding economic opportunities. Moreover, in the absence of a program specifically for the long-term unemployed, the repeal of Aid to Families with Dependent Children, which once served that purpose for single mothers-albeit with more stigma - was a loss to women whose jobs and working hours were threatened (Goldberg \& Collins, 2001). 
Are there lessons to be learned from the response to the attacks that both compounded and was compounded by recession? The advocacy and service provided by nongovernmental organizations, particularly the labour movement, increased access to UI and other benefits and, in some instances, affected actual eligibility rules. The response of the labour movement not only aided both union and non-union workers but, by winning respect for and loyalty to organized labour among those assisted, may well have offset potential membership losses. Since industries in some of the affected areas were highly unionized, there could, without this mobilization, have been a blow to an already weakened movement. Nor is the danger averted. With regard to the airline industry, we emphasized what discussions with representatives of other industries also related: that 11 September provided an opportunity to lay off or wring concessions from workers. In the case of the airlines, the federal government made its aid contingent on concessions from labour.

Renewed action to reduce economic inequality and the disadvantaged position of women in the labour market would, in the future, make it unnecessary to raise the question of this paper, namely whether women suffered worse than men. It would both reduce hardships and equalize residual disadvantage.

The sudden job losses in the aftermath of 11 September demonstrated and underscored the need for reform of an inadequate unemployment insurance system, especially for the many contingent and low-paid workers in the economy who are disproportionately women workers. Although we did not have a chance to study the policies extensively, it seems that the ready response of one state, Hawaii, was to stimulate employment through direct job creation and government bonds for construction. Perhaps this is one reason why unemployment in a state heavily dependent on tourism did not rise to predicted levels. Such an approach has the potential for expanding both human resources and the physical infrastructure (Harvey, 2001).

The governmental response in the months following 11 September, however lopsided, was greater than in an ordinary recession and may well have kept both the terrorist attacks and the gathering economic clouds from creating an even more stormy economy. Government intervention in the economy, so vilified, particularly in the United States, in the years of free-market militancy, may have been revived, although the distribution of government resources, with Washington's huge increase in military spending, exacerbated the neglect of already under-financed human services. 


\section{References}

Armshaw, J. (2001). Airlines: An industry in rough weather, in "Perspectives on Work", vol. 5, p.2. Asian American Federation of New York (2002). Chinatown after September $11^{\text {th }}$ (New York).

Berner, R. (2001). “Wichita: Not so far from ground zero", in Business Week, October 8, p. 66.

Bernstein, N. (2000). "Family needs in city exceed poverty line study says", in. New York Times, September 30, B1, B6.

Birnbaum, J. (2001). "PB Getting back to work", in America@Work, Nov./Dec. (Washington, D.C.: AFL-CIO), p.8.

Corcoran, T., Jr. (2002). "Hotels are being built, managed, renovated and operated more effectively than ever before", in Business Travel News, May 27.

DeFreitas, G. (2002). "Recession and rebuilding in the New York economy", in Regional Labor Review", vol. 4, Spring/Summer, pp. 3-19.

Emsellem, M. J. Goldberg, R. McHugh, W. Primus, R. Smith, and J. Wenger. (2002). "Failing the unemployed: A state by state examination of unemployment insurance systems" (Washington, D.C.: Economic Policy Institution, with the Center on Budget and Policy Priorities and National Employment Laws Project).

Fiscal Policy Institute. (2001). Economic impact of the September 11 World Trade Center Attack, Preliminary report, September 28. (New York).

. (2001). World Trade Center job impacts take a heavy toll on low-wage workers. November 5. (New York).

. (2002). The employment impact of the September 11 World Trade Center attacks: Updated estimates based on the benchmarked employment data. March 8 (New York).

Ginsburg, H. L. (2000). "Employment statistics: Let's tell the whole story, in Uncommon Sense, vol. 4, February 4, (New York: National Jobs for All Coalition).

Goldberg, G. S., \& S. D. Collins (2001). Washington's new poor law: Welfare "reform" and the roads not taken, 1935 to the present. (New York: Apex).

Goldberg, G. S. (2002). "The United States: More than reluctant", in G. S. Goldberg and M. G. Rosenthal, eds., Diminishing welfare: A cross-national study of social provision. (Westport, CT: Auburn House).

Harvey. H. (2001). "Responding to rising unemployment: Can we afford jobs for all?" in Uncommon Sense, vol. 14, October (New York, National Jobs for All Coalition).

Holzer, H.(2000). Assessing the new federalism. Unemployment insurance and welfare recipients: What happens when the recession comes? Policy Brief A-46 (Washington, D.C.: Urban Institute). 
Institute for Women's Policy Research (2001). Women heads of families hard hit by recession. News release, December 7 .

Langdon, D. S., T. M. McMenamin \& T. J. Krolik (2001) "U. S. labor market in 2001: Economy enters a recession", in Monthly Labor Review, February.

Leonhardt, D, (2002). "Six months later, there's the little recession that couldn't", in New York Times February 10, Sec. 3, p. 4.

Lovell, V., \& C. Hill. (2001). Today's women workers: Shut out of yesterday's unemployment insurance, IWRP Publication \#A127, May (Washington, D.C.: Institute for Women's Policy Research).

Madrick, J. (2002). "By some measures, there's still a need for government to prime the pump", in New York Times, April 8, p. C2.

Mishel, L., J. Bernstein \& J. Schmitt. (2001). The State of working America 2000-01 (Ithaca, NY: Cornell University Press).

Neely, C. J. (2002). The Federal Reserve's response to the September 11 attacks. (St. Louis: Federal Reserve Bank of St. Louis).

Pastor, M., \& C. Zabin (2002). Recession and reaction: The impact of the economic downturn on California labor. Draft. Santa Cruz and Berkeley: University of California.

Pavy, G. (2002). Announced layoffs of women post 9/11. June 27 (Washington, D.C.: AFL-CIO).

Richards, C. (2002). "Poll: Women worry more now about jobs, health care", in Women's eNews. January 6. http://www.womenssssenews.org/articlee.cfm.dyn/aid/775/context/archive

U. S. Bureau of the Census. (2001). "Money income in the United States: 2000," in Current Population Reports, pp. 60-213. Washington, D.C. United States Government Printing Office).

U.S. Department of Labor, Bureau of Labor Statistics. (2002a). Impact of the events of September 11, 2001 on BLS nonfarm payroll employment series, January 4. (Washington, D.C.), http://www.bls.gov/web/cesspec.htm

(2002b) Extended mass layoffs in the first quarter of 2002, May 16. USDL release $02-291$ (Washington, D.C.). May (Washington, D.C.).

(2002c). Highlights of women's earnings in 2001, Report 960, . (2002d) Unpublished data on mass layoffs, July 2002.

. (2002e). Unpublished nonfarm payroll employment data, July 2002.

U. S. Department of Labor, Employment and Training Administration (2002). Unpublished data on unemployment benefits for 2001 .

United Way of New York. (2002). Beyond ground zero: Challenges and implications for human services in New York City post September 11.March. (New York). 
Ward, R. (2001). "The crisis through a flight attendant's eye: This is the thanks we got", in Against the Current, Nov. http://www.igc.org/solidarity/atc/95WARD.html

(2002). "September 11 and the restructuring of the airline industry", in Dollars and Sense, May/June. http://www.dollarsandsense.org/archives/2002/0502ward.

Wenger, J. (2001). Divided we fall: Deserving workers slip through America's patchwork unemployment insurance system (Washington, D.C.: Economic Policy Institute).

. (2002). "The continuing problems with part-time jobs", in EPI Issue Brief \# 155, April 24. (Washington, D.C., Economic Policy Institute).

Wolff, G. (2001). Summary of information about unions affected by September 11. Oct. 29. Los Angeles: Center for Regional Employment Strategies and Los Angeles County Federation of Labor, AFL-CIO).

Wong, E. (2002, a). “Airline fails to win over a key union”, in New York Times, June 22, p. C3.

. (2002b). "US grants initial backing to US Airways for guarantee", in New York Times, July 11, pp. C1, C2.

pp. C1, C18.

. (2002c). "United wants loan backing to US", in New York Times, June 25,

Wong, J. (2002). "Immigrants and the aftershocks: Chinatown continues to struggle". in Gotham Gazette, Feb. http://www.gothamgazette.com/immigrants/feb.02.shtml

Zaccone, J. (2002). "Is the recession over?" in Good Jobs for All, June. (New York: National Jobs for All Coalition). 


\section{Interviews}

This report could not have been completed without the help of many people who willingly and generously shared information, provided data, and helped us to make nationwide contacts. Our special thanks go to Solidelle Wasser, an economist at the New York office of the U. S. Department of Labor, Bureau of Labor Statistics, who provided us with data, helped us conceptualize our task, and was always available to us.

The BLS office in Washington, DC also provided invaluable assistance, especially Sharon Cohany, Julia Hatch, Lewis Siegel, Laurie Salmon, and John Stinson; so did Darryl Bauman and Tom Stengle of the U.S. Department of Labor, Employment and Training Administration. We also gratefully acknowledge the help of the following persons throughout the United States who helped in various and invaluable ways:

Audrey Arnold, United Labor Agency of Nevada (AFL-CIO Community and Social Services).

Al Abromitis, International Association of Machinists, Local 1759 (Airports in Washington,

D.C. metropolitan area)

Ellen Bravo, 9 to 5, National Association of Working Women, Milwaukee, WI

Jim Brown, New York State Department of Labor, New York, NY

Heather Boushey, Economic Policy Institute, Washington, D.C.

Lawrence Boyd Center for Labor Education and Research, University of Hawaii, West Oahu, Hawaii

Mary Chen, UNITE garment workers local, New York, NY

Maggie Cook, Coalition of Labor Union Women (CLUW), Los Angeles, CA

Cynthia B. Costello, Women's Research and Education Institute

Tim Costello, North American Alliance for Fair Employment, Boston, MA

Susan Cowell, UNITE, AFL-CIO (National Office, garment workers union)

Jim DuPont, Hotel Employees and Restaurant Employees Union, Chicago, IL and Oakland, CA

Carol Eickert, Public Policy Department of the AFL-CIO, Washington, D.C.

Ellie Glenn, retired union organizer, Los Angeles, CA

Heather Healy, Employee Assistance Program, Association of Flight Attendants (AFA),

Washington, D.C.

John Heimlich, Air Transport Association of America, Washington, D.C.

Mark, Levinson, Community Service Society, New York, NY

Ruth Messinger, American Jewish World Service, New York, NY

Theresa McGlauflin, Association of Flight Attendants, Washington, D.C.

Karen Nussbaum, Working Women's Department of the AFL-CIO, Washington, D.C.

Peter Olney, Institute for Labor and Employment, University of California, Berkeley, CA

James Parrott, Fiscal Policy Institute, New York, NY

Gordon Pavy, Corporate Affairs Department, AFL-CIO, Washington, D.C.

Daille Pettit, American Hotel and Lodging Association, Washington, D.C.

Jorge Rivera, Hotel Employees and Restaurant Employees Union, Local 25, Washington, D.C. 
Amanda Ream, Hotel Employees and Restaurant Employees Union, Local 100, Food Service Union, New York. NY

Carol Rosenblatt, Coalition of Labor Union Women (CLUW), Washington, D.C.

Chao Chee Sim, Asian American Federation of New York

Rich Templin, Florida State AFL-CIO, Tallahassee, FL

John Turciano, Hotel Employees and Restaurant Employees Union, Local 6, New York, NY

Edwin Valdez, Worker Resources Center, Hotel Employees and Restaurant Employees Union, Los Angeles, CA

Rodney Ward, Dollars and Sense (magazine), a laid-off flight attendant

Kent Wong, Institute for Labor and Employment, University of California, Los Angeles, CA

Goetz Wolff, Los Angeles County AFL-CIO and Center for Regional Employment Strategies, Los Angeles, CA

Carol Zabin, Institute for Labor and Employment, University of California, Berkeley, CA

We were unsuccessful in reaching some persons; a few persons in the hotel industry (management) declined to be interviewed. 



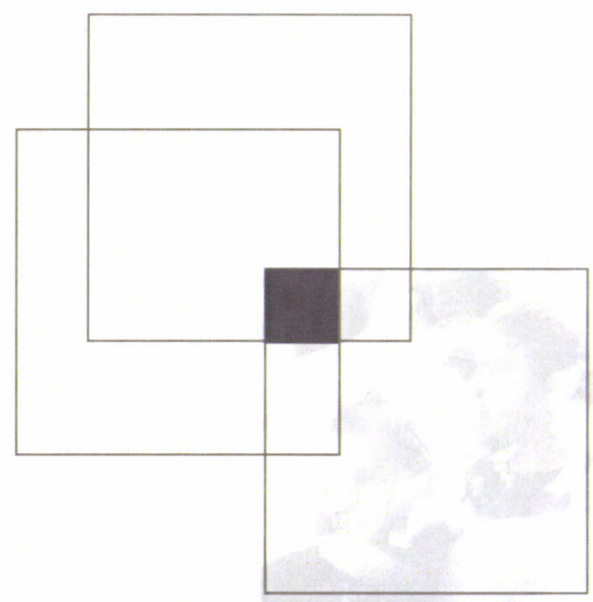

Working papers

are preliminary documents

circulated to stimulate discussion

and obtain comments...

Integration

\section{FOR MORE INFORMATION}

Policy Integration Department

International Labour Office

4 , route des Morillons

CH-1211 Geneva 22

Switzerland

Tel.: (+41 22) 7996030

Fax: (+41 22) 7997104

E-mail: integration@ilo.org

Internet: www.ilo.org 